\title{
The Development and Performance Measurements of Educational Programs to Improve Consumer Health Information (CHI) Literacy
}

\section{Younghee Noh}

Younghee Noh (irs4u@kku.ac.kr) has an MA and a PhD in Library \& Information Science from Yonsei University, Seoul. Since 2004, she has been Professor in the Department of Library \& Information Science at Konkuk University, where she teaches courses in Metadata, Digital Library, Processing of Internet Information Resources, and Digital Contents.

This work was supported by Konkuk University in 2013 (This study was begun in 2011 to be supported in 2013). The authors want to thank anonymous RUSQ reviewers for their thoughtful and constructive comments that helped to improve this paper. The author would also like to thank Patricia Ladd for editing this article into fluent English.
Reference \& User Services Quarterly, vol. 53, no. 2, pp. 140-54 (c) 2013 American Library Association. All rights reserved.

Permission granted to reproduce for nonprofit, educational use.
This research aimed to develop an education program for public librarians and library users and to measure the effectiveness of this program to promote Consumer Health Information (CHI) service programs in libraries. This study provided CHI education for librarians and users and then examined how the education program affected their perception of $\mathrm{CHI}$. After developing the education program, the author analyzed the change in perception, knowledge, and satisfaction of $\mathrm{CHI}$ in users and librarians before and after the program was administered. The author observed improvement in familiarity with CHI terminologies, knowledge of health-related websites and information sources, and ability to find health-related information on the Internet in both librarian and users groups. The research also revealed librarians' difficulty in providing $\mathrm{CHI}$ reference service and a possible solution: including education on $\mathrm{CHI}$ in the regular curriculum for public librarians. This study also provides content expectations for CHI education.

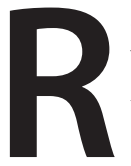
ecently, health information has been a focus of attention, and numerous researchers have demonstrated that library users seek Consumer Health Information (CHI) services and health-related education programs. ${ }^{1}$
Health Literacy is defined as an ability to obtain and process basic health information and services to obtain a proper health diagnosis. ${ }^{2}$ This definition includes finding information sources on the Internet, searching in online databases such as MedlinePlus and National Library of Medicine, selecting and evaluating reliable $\mathrm{CHI}$ sources, searching for up-to-date research information about diseases and disabilities, and obtaining license information for health care providers including medical doctors. ${ }^{3}$ Health-related education is vital to improving health literacy, both for librarians and library users. In many countries, including the United States and the United Kingdom, libraries have acknowledged the demand for $\mathrm{CHI}$ sources, and developed and provided education programs to satisfy users' demands. Moreover, medical libraries, university libraries, and public libraries have worked together to pursue specialized CHI-related user education.

However, even though studies have shown that public library users' demand for CHI-related services or education programs is relatively high in Korea, ${ }^{4}$ Korean libraries have not been providing any systematically developed education programs. Moreover, there has been no cooperation between 
different types of libraries in Korea to provide CHI service.

The goal of this research is to develop an education program for public librarians and library users and to measure its effectiveness, and, through this, to contribute to promoting CHI programs in libraries. Specifically, the author developed a health information education program, applied it to librarians and library users to measure its effectiveness, and conducted a satisfaction analysis to assure its suitability for librarians and library users. In addition, the author developed a website to support this educational program which can be used by public librarians in future.

The expected results of this research are as follows: First, measuring the change in perception among librarians and library users regarding $\mathrm{CHI}$ and library service quality to make suggestions for the improvement of future $\mathrm{CHI}$ education programs. Second, by obtaining expertise in $\mathrm{CHI}$ and a wide range of knowledge on $\mathrm{CHI}$ sources, librarians will be able to provide $\mathrm{CHI}$ services with confidence and educate users on the subject. Finally, users who received $\mathrm{CHI}$ user education will be able to access high quality $\mathrm{CHI}$ sources on the Internet and obtain precise information about their own health, which contributes to their own healthy life.

\section{LITERATURE REVIEW}

Due to an increase in available consumer health information sources, the librarian's role as an evaluator and provider of reliable $\mathrm{CHI}$ sources has become more important than ever. For this reason CHI-related education programs for improving $\mathrm{CHI}$ literacy must be studied and developed. Moreover, to improve the effectiveness of such programs, various CHIrelated sites and databases should be constructed and offered.

\section{Research and Development of Librarian Education Programs}

Benedetti pointed out that even though public librarians are in a position to provide $\mathrm{CHI}$-related reference service, libraries cannot afford to expand their medical and CHI-related collections, and librarians are afraid of providing incorrect medical advice. ${ }^{5}$ Librarians who have received sufficient training can manage information resources and provide reference service in almost all areas, but, nevertheless, they are experiencing difficulties in answering CHI-related questions.

Therefore education programs for librarians need to be studied and developed. The Carnegie Library of Pittsburgh (CPL), for example, planned a librarian education program for $\mathrm{CHI}$ service improvement that focuses on consistent and high-quality consumer health assistance. Clark briefly explained that CPL put priority on staff education related to consumer health information, studied demand from both the staff and local community, and provided an education to meet the identified needs. ${ }^{6}$ In addition, he showed that staff competence had improved after the education and gave an analysis of the educational contents and curriculum developed for the training

The National Network of Libraries of Medicine (NNLM) developed education resources and outreach services for those who want to know how to find CHI efficiently and for librarians who seek to educate library users. The NNLM website provides various information sources related to $\mathrm{CHI}$ and free training programs including information about Regional Medical Libraries (RMLs). The Educational Clearinghouse database also provides educational materials related to biomedical and health problems. ${ }^{7}$

There have been many cases of different types of libraries cooperating for librarian education. The project conducted by the Texas Woman's University and the Dallas Public Library (DPL) is an example of a collaboration effort for $\mathrm{CHI}$ resources in public libraries. The purpose of this project was to meet the educational needs of public librarians and library users by supporting the development of web-based educational materials and providing training programs. The training was designed and implemented for practical and web-based education; public library reference librarians received education and support for providing users with $\mathrm{CHI}$ services. Snyder, Huber, and Wegmann analyzed this program, which provided DPL staff with high-quality $\mathrm{CHI}$ training, and found that the project represented a successful cooperation between public and university libraries that contributed to the identification and resolution of cultural, linguistic, and practical problems in the CHI field. ${ }^{8}$

There have also been many cases of different types of libraries cooperating to develop online $\mathrm{CHI}$ resources, or librarians from different types of libraries working together to improve the effectiveness of librarian education. In February 2000, the Health Sciences Library System (HSLS) of the University of Pittsburgh conducted an NLM-funded project for developing a CHI electronic resource, which could be accessed by the general public. This Access to Electronic Health Information project, which offered $\mathrm{CHI}$ training to librarians from public libraries in 16 counties, aimed to (1) improve consumer knowledge about $\mathrm{CHI}$ and the accessibility of $\mathrm{CHI}$, (2) improve $\mathrm{CHI}$ literacy by educating users on how to search for reliable and authoritative $\mathrm{CHI}$ resources, and (3) clarify the role of MedlinePlus and PubMed in the CHI search. Wessel, Wozar, and Epstein evaluated this program and concluded that the university medical libraries contributed to the local community by offering $\mathrm{CHI}$-related education. ${ }^{9}$

In 1998, the librarians from the L. Sharp Health Sciences Library at Cooper Hospital/University Medical Center started to develop webpages as a tool for their class Consumer Health Resources on the Web. These webpages, containing $\mathrm{CHI}$-related information sources as well as teaching tips, were expanded and revised to support various additional classes and now form an essential resource for educating patients and staff. ${ }^{10}$ The reference librarians who participated in this program are from public, university, and medical libraries.

Treadwell Library in the Massachusetts General Hospital established the Consumer Health Reference Center (CHRC), which enables cooperative service between librarians and 


\section{FEATURE}

allows librarians to use the system regardless of their library type. The system provides practical information, newsletters, website information, print and electronic resources, continuing education workshop information, CHI-related frequently asked questions, and various statistical information. ${ }^{11}$

\section{Research and Development of User Education Programs}

The objective of CHI-related user education is to improve user's health information literacy. Users with good health information literacy skills can locate and understand appropriate $\mathrm{CHI}$ sources, and make the right decision on healthrelated issues.

Parker and Kreps emphasized the effect of users' health information literacy on their usage of $\mathrm{CHI}$ sources. ${ }^{12}$ They analyzed the problem within a vulnerable social group, surveyed advantages and disadvantages of various $\mathrm{CHI}$ programs, and proposed a strategy to improve health literacy. Burnham and Peterson suggested that public libraries can participate in the circulation of health information written in understandable language through case studies and concluded that libraries and librarians can contribute to their local community by improving users' health information literacy and continually discussing the relevant issues. ${ }^{13}$ Kloda surveyed the current status of health literacy education in Canada. ${ }^{14}$ In 2006, McGill University also conducted a phone survey on whether $\mathrm{CHI}$-related education and activities are provided to Medical school students and found that 14 out of 17 universities are providing CHI-related education programs. ${ }^{15}$

There have also been some large-scale, library-level CHI literacy improvement projects. Kaleida health libraries conducted Seniors Connect: A Health Information Project in cooperation with the Buffalo and Erie County Public Library and supported by the Community Foundation for Greater Buffalo. The objective was to teach seniors, especially African Americans and Hispanics, how to search for precise and comprehensible high-quality $\mathrm{CHI}$ on the Internet. Over the course of 14 lessons, the participants learned how to distinguish high-quality $\mathrm{CHI}$ from inaccurate, questionable, and fraudulent sources. Moreover, the Senior Connect program offered education on public health services available in the local community, a demonstration of proper $\mathrm{CHI}$ searching on the Internet, information on treatment methods for high blood pressure and diabetes, and opportunities to interact with health service providers and librarians. The program was highly rated by participants and recognized as an attractive program for senior citizens. ${ }^{16}$

Other examples of large scale database development for literacy improvement are (1) Web Health for Seniors in 2002, in the United States, supported by NNLM and Southeastern Atlantic Regional (SE/AR) Medical Library of University Maryland ${ }^{17}$ (2) the Consumer Health Database Searching Seminar (CHDSS) series designed by Brigham and Women's Hospital to educate patients, patients families, and caregivers; (3) Health Information Literacy Outreach project conducted in 2008 by the nonprofit organization River Valley Healthy Communities Coalition (RVHCC) to improve health information accessibility and health literacy:18 and (4) Healthy websites (Healthnet) developed as a result of the Health Information Literacy Outreach project by local public libraries to provide high-quality health information to Connecticut residents, among others. ${ }^{19}$ From careful analysis of the above education programs for librarians and users as well as the related research, the researchers have derived the following implications. First, public libraries that are interested in $\mathrm{CHI}$ service put emphasis on the librarian's role as a $\mathrm{CHI}$ evaluator and provider and provide $\mathrm{CHI}$ education programs for librarians to improve their CHI-related ability. Second, they cooperate with other types of libraries such as university libraries and medical libraries to provide CHI-related education. Third, the Medical Library Association directly supports librarian education by providing free training, educational databases, and CHI workshop series and websites. Fourth, medical libraries often educate reference librarians from various other types of libraries, and their education materials are often developed and provided as websites. The Treadwell Library in Massachusetts General Hospital, especially, provides newsletters, website information, print and electronic collections, continuing education workshop information, $\mathrm{CHI}$-related frequently asked questions, and various statistical information. Fifth, a number of CHI-related education program development projects have been implemented, and education programs as well as health-related websites are provided to increase health-related information accessibility. Finally, various forms of education are available such as Consumer Health Database Searching Seminars, Healthnet, and WebHealth for Seniors.

\section{RESEARCH QUESTION}

This study involved developing a CHI-related education program and offering it to both public librarians and users, then measuring the program's effect and trying to identify issues for improvement. This study represents the first time such research has been conducted in Korea. The research questions are:

- RQ 1: Are librarians and library users accustomed to consumer health information terminologies?

- RQ 2: What are the most obvious difficulties for public librarians when offering $\mathrm{CHI}$-related reference services? What should be the focus when educating them in this area?

- RQ 3: Does CHI education significantly improve users' ability to search for health-related information on the Internet?

- RQ 4: Do public librarians and users want to receive CHIrelated education?

- RQ 5: Does CHI education significantly affect librarians' and users' perceptions of $\mathrm{CHI}$ and $\mathrm{CHI}$ library service? 
Table 1. Contents of education program designed for public librarian and user CHI education

\begin{tabular}{|c|c|c|}
\hline & Librarian & User \\
\hline Place & Konkuk University & 2 public libraries \\
\hline Instructor & $\begin{array}{l}\text { Instructor: Three public librarians } \\
\text { Panel: } 2 \text { public librarians for each subject } \\
\text { ( } 6 \text { in total) }\end{array}$ & Public librarian (library A: 3, library B: 1) \\
\hline Topic & $\begin{array}{l}\text { CHI and the library } \\
\text { - Topic 1: Meaning of CHI services for the } \\
\text { public library } \\
\text { - Topic 2: CHI examples and status } \\
\text { (in Korea and abroad) } \\
\text { - Topic 3: CHI usage in public libraries }\end{array}$ & $\begin{array}{l}\text { Improving CHI utilization ability (Internet } \\
\text { information resources) } \\
\text { - Topic 1: CHI service provided by public library } \\
\text { - Topic 2: CHI Internet information sources on } \\
\text { public library homepage } \\
\text { - Topic 3: how to use CHI sources } \\
\text { (in addition, other activities such as "practice using } \\
\text { information sources in various media" and "practice } \\
\text { Tai Chi and learn the effect of Tai Chi") }\end{array}$ \\
\hline Period & 1 day & 3 weeks \\
\hline Measurement & Survey (twice: before and after the education) & \\
\hline Participants & $\begin{array}{l}16 \text { public librarians ( } 12 \text { responded) } \\
40 \text { students taking reference information class }\end{array}$ & $\begin{array}{l}42 \text { public users (had more participants, but only } \\
\text { counted those who participated during the entire } \\
\text { period) }\end{array}$ \\
\hline Motto & CHI Service Movement in Korean Libraries & \\
\hline $\begin{array}{l}\text { Instructional Design } \\
\text { and Completion Time }\end{array}$ & Nov. 14, 2011-May 15, 2012 & Nov. 14, 2011-Oct. 22, 2012 \\
\hline
\end{tabular}

The researchers developed and conducted a survey regarding the above questions, and then analyzed and discussed the results to propose answers to them.

\section{RESEARCH DESIGN AND METHOD}

This research aims to provide CHI-related education for librarians and users, and investigate how the education changes current librarian and user perceptions. To this end, the researchers developed an education program and analyzed changes in perception, knowledge, and satisfaction in both groups before and after the education program.

\section{Education Program Design}

Considering that CHI-related topics are not well-known and there has been no consensus on $\mathrm{CHI}$ services provided by public libraries in Korea, the researchers chose relatively simple topics for the education curriculum. The education topics were selected based on several discussions between researchers and lecturers. The lectures were prepared and advertised for about two years.

The educational topics covered for librarians were the definition of $\mathrm{CHI}$ service, reasons for public libraries to provide CHI service, the current status and examples of CHI service, both in Korea and abroad, and the use of more than 10 different CHI resources. The topics covered for users were: an introduction to easily accessible CHI resources, an explanation of their use, and actual practice using them.

The researchers chose a seminar and discussion format as the education method for the librarians. After an instructor's talk, participants had a discussion on what CHI-related service public libraries should be providing and how librarians can improve users' CHI literacy. The instructors were three librarians who have a particular interest in health. The user education sessions were offered by librarians who had experience and training in $\mathrm{CHI}$.

The education program used as a text a four-book series and website on health-related information resources developed for this project (www.healthportal-korea.net), ${ }^{20} 10 \mathrm{CHI}-$ related web information source manuals, and lecture notes provided by the instructors (see table 1).

For the education program, the researchers developed, for the first time in Korea, a CHI portal site HealthPortal-Korea (HPK), to provide high-quality CHI services in libraries (see figure 1). This site is designed to systematically collect $\mathrm{CHI}$ sources and to play the role of CHI medium. It introduces domestic and overseas health information sources and provides relevant books, papers, and educational materials. Its health information resource section provides 111 domestic health information sources and 80 overseas health information 


\section{FEATURE}

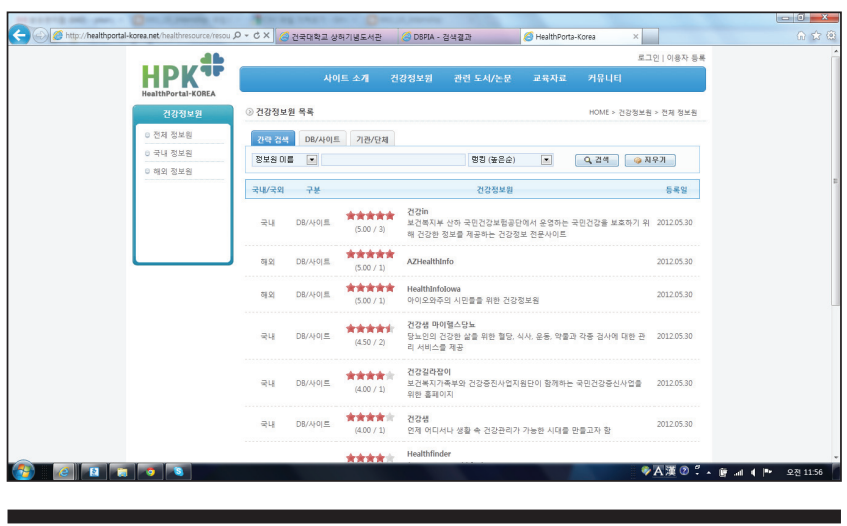

Figure 1. HealthPortal-Korea website

sources along with a 5-star consumer rating function. Its books and papers section introduces health-related book and papers, and the educational materials section provides resources for librarian and user education. The site also has community tools which enable librarians and users to exchange CHI-related questions and answers.

\section{Sampling and Data Collection Process}

The researchers measured the effect of the librarian and user education programs by comparing participants' responses to surveys before and after the program. To have a meaningful comparison, the researchers provided the educational program to librarians who had an interest in the topic and a desire to participate in the development of education programs. Moreover, their libraries had to be equipped to provide such an experimental program with the proper amount of space and time, director approval, and staff interest.

To determine librarians who had an interest in the topic, the researchers (1) analyzed 129 public library homepages which provide CHI service out of 748 registered in the 2010 Korean Library Year Book; ${ }^{21}$ (2) surveyed reference librarians from those 129 libraries, and 56 librarians responded; 22 (3) assumed that the 56 librarians were the most interested in participating in $\mathrm{CHI}$ education and asked them to participate via phone call-12 librarians agreed; and (4) Since this program is the first CHI training for public librarians, the researchers selected "CHI Service Movement in Korean Libraries" as the motto, and advertised the program in various media to highlight its meaning and significance. More specifically, the researchers actively advertised the program twice through a mailing list for librarians and other information professionals, "Domeri," which has more than 10,000 members, including librarians, students, and professors, and students who were taking reference information resources classes were also given the opportunity to participate.

As a result, more than 16 librarians and more than 40 undergraduate and graduate students participated in the seminar. The survey was conducted only for the public librarians and 12 of them responded.

The survey asked the 12 librarians whether they could provide CHI education to users in their library, given both their individual skills and library conditions. Initially, four librarians replied that they could provide the education in their libraries to aid the study, but two of them were eventually forced to cancel despite their best efforts due to unavoidable circumstances. To recruit user participants for $\mathrm{CHI}$ education programs, the researchers posted a link to the $\mathrm{CHI}$ portal developed for this research on the main pages of the participating libraries' websites as well as posters on the bulletin boards in those libraries (see figure 2). The promotion period for this was about 2 months.

Sixty user participants attended the sessions in total, but the researchers performed analysis on responses from only 42 participants, those who attended all the sessions without absences.

\section{Survey Contents and Description}

The questions used in this research were developed based on a variety of survey questionnaires measuring the effectiveness of CHI service education from previous research as well as their results. The papers analyzed to develop the librarian survey were work by (1) Wu et al., which introduced various education methods using web-based, workshop, education toolkit, and video education; ${ }^{23}$ (2) Snyder, Huber, and Wegmann, which evaluated and studied a successful cooperation program between public libraries and university libraries, ${ }^{24}$ and (3) Wessel, Wozar, and Epstein, which provided and evaluated CHI training for public librarians in 16 counties in Pennsylvania. ${ }^{25}$ The final survey questionnaire contains questions about the current status of CHI service, the effect of CHI education and issues for improvements, and respondents' demographic characteristics.

The papers analyzed to develop the user survey were about (1) deducing demand for CHI education service; ${ }^{26}$ (2) surveying the current status of health information literacy education; ${ }^{27}$ and (3) analyzing performance of the health information website Healthnet. ${ }^{28}$ The final survey questions include the current status of $\mathrm{CHI}$ usage, the effect of $\mathrm{CHI}$ education and issues for improvements, and respondents' demographic characteristics.

\section{RESULTS}

\section{Demographic Characteristics of Respondents}

Sixteen public librarians participated in the librarian education portion of this research along with 40 college students taking a course about reference information resources. Among these, 12 librarians took the preeducation survey and 14 did the post-education survey. To measure the effects of the program, the study excluded the two librarians who did not respond to the preeducation survey from. The researchers did not survey the college students either, since the training was designed only for currently active librarians and it was felt that their results would not accurately reflect 

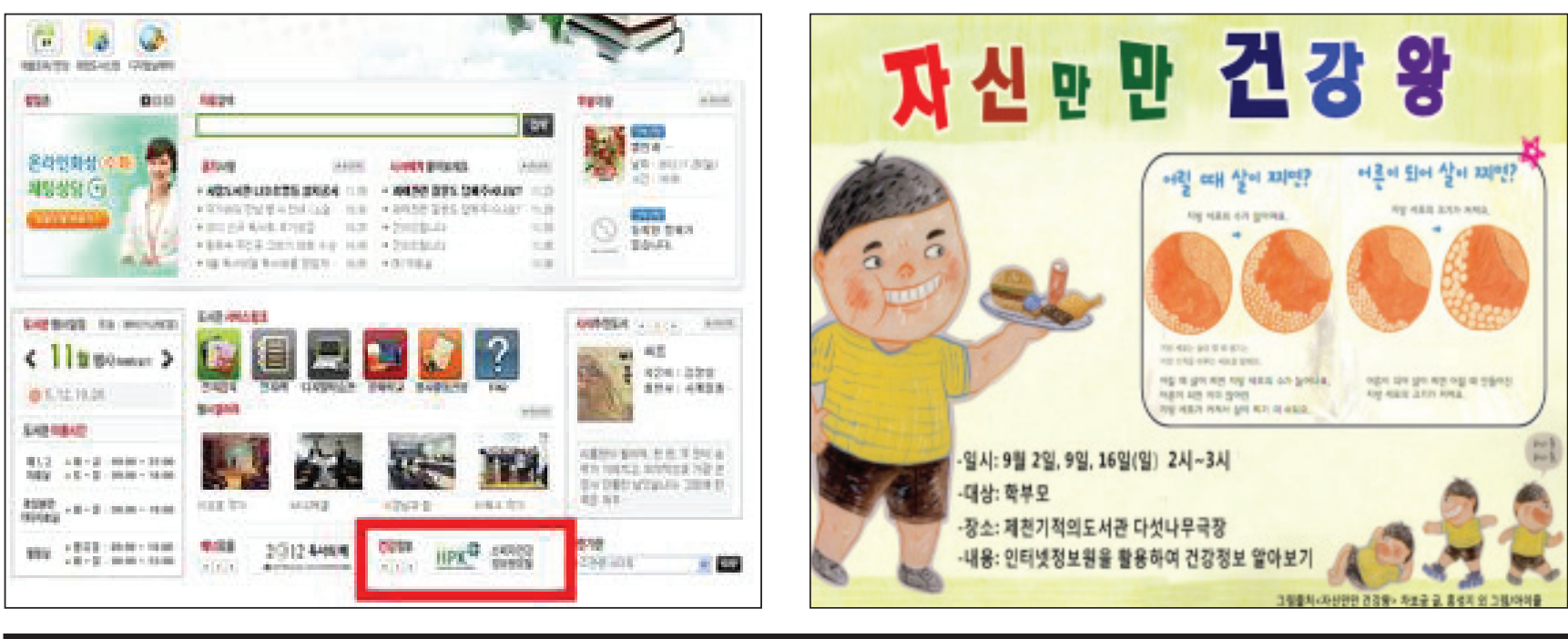

Figure 2. $\mathrm{CHI}$ education program promotion. Left: promotion on the library websites. Right: promotion poster.

the realities of the workplace. The students were allowed to participate only for their own educational purposes. Of the surveyed librarians, the gender proportion was $16.7 \%$ males and $83.3 \%$ females. The age distribution across the group is as follows: 20 to 29 years, $16.7 \%$; 30 to 39 years, $33.3 \%$; 40 to 49 years, $25 \%$; 50 to 59 years, $16.7 \%$; nonrespondents, $8.3 \%$. The distribution of degree level in library and information science was: doctorate degree, $8.3 \%$; master's degree, $25 \%$; bachelor's degree, $50 \%$; non-respondents, $8.3 \%$. Their positions in the library were defined as the two positions in which they have spent the longest time, both reference service and management/planning were the highest percentage with $41.7 \%$. The other categories represented were: acquisition at $33.3 \%$, user education at $25 \%$, and classification and cataloging at $16.7 \%$. The user education program had 63 total participants. The length of the program was 3 weeks, and the subjects of analysis were the 42 users who participated for the entire program without absence (66.67\% percent of the total). The gender proportion was $26.2 \%$ males to $71.1 \%$ females ( 1 nonrespondent). The age group distribution was as follows: 20 to 29 years, $28.6 \%$; 30 to 39 years, $21.4 \%$; 50 to 59 years, $4.8 \%$; 60 to 69 years, $11.9 \% ; 70$ to 79 years, $14.3 \%$. To identify their individual Internet usage behavior, the survey asked how many hours they spent on the Internet per day, and those who answered 1 to 2 hours had the highest proportion (40.5\%) followed by less than 1 hour (28.6\%). On the education post-survey, the proportion who answered 2 to 3 hours increased slightly. User participants were also asked how frequently they use the Internet to search for health information, and those who answered "1 or 2 times" had the highest proportion and "never" had the second highest. However, after the education, the proportion of "never" had decreased from $45.2 \%$ to $28.6 \%$. The education significantly increased the proportion of users who use the Internet to search for health information $(\mathrm{p}=0.0377)$.

\section{Analysis on the Effect of Education}

The researchers developed 10 questions to measure the effects of the $\mathrm{CHI}$ education program. The same questions were asked before and after the program. Some of the questions were the same for the librarians and users, while others were not.

\section{Comparing the Perception of Librarians and Users}

\section{Familiarity with CHI Terminologies}

The researchers compared familiarity with $\mathrm{CHI}$ terminologies before and after the program in both the user group and the librarian group. In the librarian group, the proportion of librarians who were familiar with $\mathrm{CHI}$ terminologies increased, and the proportion of those who were not familiar decreased considerably. Specifically, the librarians who answered that they were "familiar" with $\mathrm{CHI}$ terminologies increased from $8.3 \%$ to $25 \%$, and those who answered "not familiar" decreased from $75 \%$ to $33.3 \%$. However, the difference was not statistically significant, most likely due to the small sample size. None of the participants answered that they were "very familiar," probably because of the short program period which may not be sufficient to give them confidence.

The researchers also measured improvement in familiarity of $\mathrm{CHI}$ terms in the user group. As a result, the proportion of those users who were familiar with $\mathrm{CHI}$ terminologies increased from $4.8 \%$ to $21.4 \%$, and the difference was statistically significant $(p=0.0001)$. The analysis shows that the program had a significant effect on overcoming the difficulty of $\mathrm{CHI}$ terminologies, which might be the biggest obstacle for users (see table 2 and figure 3).

\section{Comparison between Demand and Supply of CHI Literacy Education}

The researchers asked librarians whether their libraries are 


\section{FEATURE}

Table 2. Familiarity with $\mathrm{CHI}$ terminologies

\begin{tabular}{|c|c|c|c|c|c|c|c|c|c|c|c|c|c|c|c|}
\hline & \multicolumn{2}{|c|}{ Sum } & \multicolumn{2}{|c|}{$\begin{array}{c}\text { Very } \\
\text { Familiar }\end{array}$} & \multicolumn{2}{|c|}{ Familiar } & \multicolumn{2}{|c|}{ Not Sure } & \multicolumn{2}{|c|}{$\begin{array}{c}\text { Not } \\
\text { Familiar }\end{array}$} & \multicolumn{2}{|c|}{$\begin{array}{c}\text { Not } \\
\text { Familiar } \\
\text { at All }\end{array}$} & \multirow[t]{2}{*}{ Mean } & \multirow[t]{2}{*}{ Std } & \\
\hline & Freq & $\%$ & Freq & $\%$ & Freq & $\%$ & Freq & $\%$ & Freq & $\%$ & Freq & $\%$ & & & \\
\hline Librarian & & & & & & & & & & & & & & & \\
\hline Pre-education & 12 & 100.0 & 0 & 0.0 & 1 & 8.3 & 2 & 16.7 & 7 & 58.3 & 2 & 16.7 & 2.167 & 0.835 & stat $=18$ \\
\hline Post-education & 12 & 100.0 & 0 & 0.0 & 3 & 25.0 & 5 & 41.7 & 3 & 25.0 & 1 & 8.3 & 2.833 & 0.937 & pValue $=0.1548$ \\
\hline User & & & & & & & & & & & & & & & \\
\hline Pre-education & 42 & 100.0 & 0 & 0.0 & 2 & 4.8 & 19 & 45.2 & 17 & 40.5 & 4 & 9.5 & 2.452 & 0.739 & stat $=179.5$ \\
\hline Post-education & 42 & 100.0 & 1 & 2.4 & 15 & 35.7 & 22 & 52.4 & 2 & 4.8 & 2 & 4.8 & 3.262 & 0.798 & pValue $=<.0001$ \\
\hline
\end{tabular}

currently providing $\mathrm{CHI}$ literacy education for users and asked users what health information they are looking for in the public library. In both the librarian group and the user group, survey results show that the demand for $\mathrm{CHI}$ education increased. There was some evidence that, after the librarian training, $\mathrm{CHI}$ literacy user education programs have become more common and various. This may imply that an increase in librarian $\mathrm{CHI}$ education can possibly increase $\mathrm{CHI}$ education for users.

Besides this, the study also found a difference in perception of the educational contents of the programs; the librarians tended to provide education programs hosted doctors or other experts, but the users demanded contents about identifying methods for reliable and high-quality health information sources (47.6 percent), searching for the latest research information about disease and disability, and health information database search and usage. This clearly shows that there is a discrepancy between supply and demand. After the education, the proportion of users demanding education programs from doctors or other experts showed the biggest increase, and this suggests that the librarians' perception affected the users' perception (see table 3).

\section{CHI-Related Information Sources}

The researchers investigated which health information sources are used by librarians and users. The information sources listed in the questionnaire were the top 15 Korean sites from the result of a CHI source evaluation survey of 20 librarians and 50 users which used the information source evaluation criteria developed by Oh and Noh in 2012. ${ }^{29}$ The study also included HealthPortal-Korea (HPK), developed for this research, and PubMed and MedLinePlus, the most frequently used sites for user education in the United States. ${ }^{30}$ The programs introduced these sites and explained their characteristics. However, only ten sites, HPK, 365Homecare, Hidoc, Vitamin MD, Konkang Sam, Comediy.com, Joins MSN Konkang In, MKhealth, Medcity, and HealthChosun, were used for demonstrations during the education program.

The study measured the frequency of usage of these $\mathrm{CHI}$ sources and found an overall increase across the sites in both

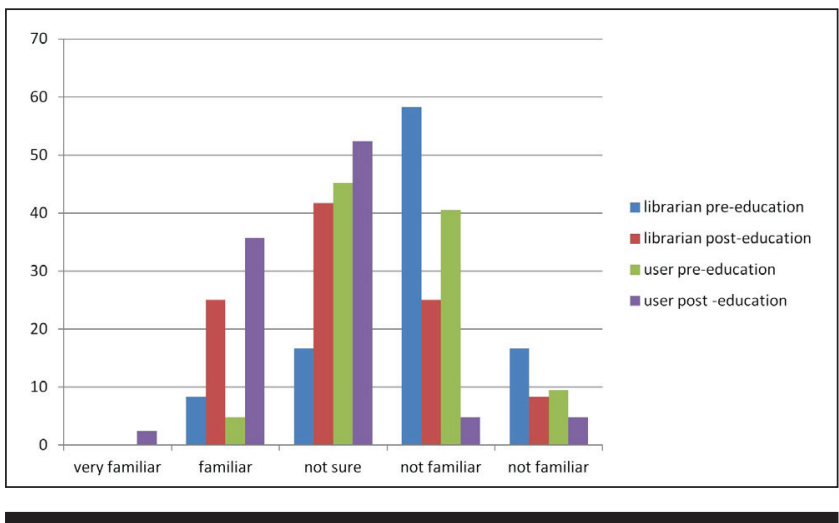

Figure 3. Familiarity with $\mathrm{CHI}$ terminologies

groups after the programs. Most especially, the sites used for demonstrations showed more of an increase. This proves that education about CHI sources can improve librarians' and users' knowledge and usage of reliable health information sources (see table 4 and figure 4 ).

\section{Useful Information Content}

The researchers asked librarians about what kinds of educational content would be useful for providing $\mathrm{CHI}$-related service, and found that the number of responses increased, listing a variety of useful content about specific diseases and symptoms, health insurance and medical benefits information, details about a particular hospital or medical center, and prescription medication and its side effects. On the other hand, respondents desiring information about alcohol consumption, diet and nutrition, and smoking decreased in the post-survey. Though there are many possible explanations for this shift, the researcher posits that it represents a fundamental change in how librarians view their role in providing $\mathrm{CHI}$. For instance, these findings may indicate that librarians previously thought that public libraries could only provide information related to less serious issues (diet, nutrition, healthy habits, etc.), but they realized during the course of the seminar that libraries could also provide information about more serious subjects, such as specific diseases and medications. 
Table 3. Comparison between supply and demand of $\mathrm{CHI}$ literacy education

\begin{tabular}{|c|c|c|c|c|c|c|c|c|c|c|c|c|c|c|c|c|c|c|}
\hline \multirow{6}{*}{$\begin{array}{l}\text { Pre-education } \\
\text { Post-education }\end{array}$} & \multirow{2}{*}{\multicolumn{2}{|c|}{ Sum }} & \multicolumn{4}{|c|}{$\begin{array}{l}\text { How to search health } \\
\text { information on the } \\
\text { Internet }\end{array}$} & \multicolumn{4}{|c|}{\begin{tabular}{|c|} 
How to take \\
advantage of health- \\
related organizations
\end{tabular}} & \multicolumn{4}{|c|}{$\begin{array}{l}\text { How to search } \\
\text { and use health } \\
\text { information } \\
\text { databases }\end{array}$} & \multicolumn{4}{|c|}{$\begin{array}{l}\text { How to find the latest } \\
\text { research information } \\
\text { about the illness and } \\
\text { disability }\end{array}$} \\
\hline & & & \multicolumn{2}{|c|}{ Librarian } & \multicolumn{2}{|c|}{ User } & \multicolumn{2}{|c|}{ Librarian } & \multicolumn{2}{|c|}{ User } & \multicolumn{2}{|c|}{ Librarian } & \multicolumn{2}{|c|}{ User } & \multicolumn{2}{|c|}{ Librarian } & \multicolumn{2}{|c|}{ User } \\
\hline & \multirow{2}{*}{$\begin{array}{c}\text { Freq } \\
42\end{array}$} & $\%$ & Freq & $\%$ & Freq & $\%$ & Freq & $\%$ & Freq & $\%$ & Freq & $\%$ & Freq & $\%$ & Freq & $\%$ & Freq & $\%$ \\
\hline & & \multirow{2}{*}{$\begin{array}{l}100.0 \\
100.0\end{array}$} & 0 & 0.0 & 14 & 33.3 & 0 & 0.0 & 9 & 21.4 & 0 & 0.0 & 15 & 35.7 & 0 & 0.0 & 10 & 23.8 \\
\hline & 42 & & 1 & 8.3 & 13 & 31.0 & 0 & 0.0 & 9 & 21.4 & 0 & 0.0 & 16 & 38.1 & 1 & 8.3 & 17 & 40.5 \\
\hline & & & \multicolumn{4}{|c|}{$\begin{array}{l}\mathrm{McN}=0.0526 \\
P_{\text {_value }}=1\end{array}$} & \multicolumn{4}{|c|}{$\begin{array}{l}\mathrm{McN}=0 \\
\mathrm{P} \_ \text {value }=1\end{array}$} & \multicolumn{4}{|c|}{$\begin{array}{l}\mathrm{McN}=0.0667 \\
\mathrm{P} \_ \text {value }=1\end{array}$} & \multicolumn{4}{|c|}{$\begin{array}{l}\mathrm{McN}=3.7692 \\
\mathrm{P} \text { _value }=0.0923\end{array}$} \\
\hline & \multirow{2}{*}{\multicolumn{2}{|c|}{ Sum }} & \multicolumn{4}{|c|}{$\begin{array}{l}\text { Identifying methods } \\
\text { for reliable and } \\
\text { high-quality health } \\
\text { information sources }\end{array}$} & \multicolumn{4}{|c|}{$\begin{array}{l}\text { How to find the } \\
\text { certification } \\
\text { information of other } \\
\text { healthcare providers, } \\
\text { including physicians }\end{array}$} & \multicolumn{4}{|c|}{\begin{tabular}{|} 
Providing education \\
program from \\
doctors and other \\
experts
\end{tabular}} & \multicolumn{4}{|c|}{$\begin{array}{c}\text { Don't have any plans } \\
\text { to provide education } \\
\text { program }\end{array}$} \\
\hline & & & \multicolumn{2}{|c|}{ Librarian } & \multicolumn{2}{|c|}{ User } & \multicolumn{2}{|c|}{ Librarian } & \multicolumn{2}{|c|}{ User } & \multicolumn{2}{|c|}{ Librarian } & \multicolumn{2}{|c|}{ User } & \multicolumn{2}{|c|}{ Librarian } & \multicolumn{2}{|c|}{$\begin{array}{c}\text { User } \\
\text { (Others) }\end{array}$} \\
\hline & Freq & $\%$ & Freq & $\%$ & Freq & $\%$ & Freq & $\%$ & Freq & $\%$ & Freq & $\%$ & Freq & $\%$ & Freq & $\%$ & Freq & $\%$ \\
\hline Pre-education & 42 & 100.0 & 0 & 0.0 & 19 & 45.2 & 0 & 0.0 & 4 & 9.5 & 1 & 8.3 & 2 & 4.8 & 1 & 8.3 & 0 & 0.0 \\
\hline \multirow[t]{2}{*}{ Post-education } & 42 & 100.0 & 1 & 8.3 & 20 & 47.6 & 1 & 8.3 & 3 & 7.1 & 11 & 91.7 & 15 & 35.7 & 0 & 0.0 & 1 & 2.4 \\
\hline & & & $\begin{array}{l}\mathrm{McN} \\
\text { P_va }\end{array}$ & $\begin{array}{l}=0.0 \\
\text { ue }=\end{array}$ & 769 & & $\begin{array}{l}\mathrm{McN} \\
\text { P_val }\end{array}$ & $\begin{array}{l}=0.1 \\
\text { lue }=\end{array}$ & 429 & & $\begin{array}{l}\mathrm{McN} \\
\mathrm{P}_{\text {_va }}\end{array}$ & $\begin{array}{l}=13 \\
\text { lue }=\end{array}$ & .0002 & & $\begin{array}{l}\text { McN } \\
\text { coulc } \\
\text { coml } \\
\text { insuf } \\
\text { obse }\end{array}$ & $\begin{array}{l}\text { and } 1 \\
\text { not } \\
\text { uted } \\
\text { icien } \\
\text { vatio }\end{array}$ & $\begin{array}{l}\text { Values } \\
\text { due to } \\
\text { numb }\end{array}$ & an \\
\hline
\end{tabular}

The survey also gave the library users the option to check all content that seemed to be useful for users to maintain a healthy lifestyle. After the education, the demand for information about recent outbreaks of disease showed a large increase from 16.7 percent to 31 percent, but the demand for information about diet and nutrition decreased from 45.2 percent to 23.8 percent. This shift is similar to that found in the librarian group, and shows that the demand for relatively simple topics may have decreased since the users can search for these by themselves after completing the training. However, the demand for information on more difficult topics increased over the course of the program. The demand for education about specific hospitals and medical institutions, specific doctors, prescription medication and side effects of medications, and health-related issues increased, but the overall demand for $\mathrm{CHI}$ education decreased. Interpreting these results positively, this overall decrease may be because users became more confident after the educational program.

As seen in the previous section about cases in other countries, public libraries abroad are already providing information about cures for specific diseases, and receiving education related to such services. ${ }^{31}$ According to the research, users first educate themselves about drug addiction, sex-related issues, depression, stress, or mental illness using the Internet or library before going to a doctor or hospital. Therefore, libraries should help users to obtain high-quality information rather than unreliable sources on the Internet. For this reason, librarians need to be trained to evaluate $\mathrm{CHI}$ sources (see table 5).

\section{Intention to Participate in CHI Education}

The researchers asked both librarians and users about their intention to participate in health-related seminars/lectures/ workshops in the future, and no librarians answered negatively even before the program, although the proportion that answered "agree" and "strongly agree" slightly increased upon completion. Before the seminar, 66.7 percent of the librarians showed their intention to participate further, and after the program, 83.3 percent agreed that they would participate again. In the user group, the proportion of those who agreed that they would participate increased from 52.3 percent to 78.5 percent, which is a 26.2 percent increase, and the corresponding p-value is 0.0024 , which is significant under the 5 percent significance level. Nobody answered that they would "strongly disagree" to participation, either before or after the program, and the proportion of "disagree" answers decreased from 7.1 percent to 4.8 percent. The user group expressed high interest in $\mathrm{CHI}$ education before the program, and it 
Table 4. Experience using CHI-related resources

\begin{tabular}{|c|c|c|c|c|c|c|c|c|c|c|c|c|c|c|c|c|c|c|}
\hline \multirow[b]{4}{*}{ Pre-education } & \multirow{2}{*}{\multicolumn{2}{|c|}{ Sum }} & \multicolumn{4}{|c|}{ PubMed } & \multicolumn{4}{|c|}{ MedLinePlus } & \multicolumn{4}{|c|}{ HealthPortal-Korea } & \multicolumn{4}{|c|}{ 365Homecare } \\
\hline & & & \multicolumn{2}{|c|}{ Librarian } & \multicolumn{2}{|c|}{ User } & \multicolumn{2}{|c|}{ Librarian } & \multicolumn{2}{|c|}{ User } & \multicolumn{2}{|c|}{ Librarian } & \multicolumn{2}{|c|}{ User } & \multicolumn{2}{|c|}{ Librarian } & \multicolumn{2}{|c|}{ User } \\
\hline & Freq & $\%$ & Freq & $\%$ & Freq & $\%$ & Freq & $\%$ & Freq & $\%$ & Freq & $\%$ & Freq & $\%$ & Freq & $\%$ & Freq & $\%$ \\
\hline & 42 & 100 & 1 & 8.3 & 2 & 4.8 & 2 & 16.7 & 1 & 2.4 & 0 & 0 & 3 & 7.1 & 0 & 0 & 4 & 9.5 \\
\hline \multirow[t]{5}{*}{ Post-education } & 42 & 100 & 2 & 16.7 & 6 & 14.3 & 1 & 8.3 & 6 & 14.3 & 6 & 50 & 8 & 19 & 4 & 33.3 & 11 & 26.2 \\
\hline & & & \multicolumn{4}{|c|}{$\begin{array}{l}\mathrm{McN}=4, \\
\mathrm{pValue}=0.125\end{array}$} & \multicolumn{4}{|c|}{$\begin{array}{l}\mathrm{McN}=5 \\
\mathrm{pValue}=0.063\end{array}$} & \multicolumn{4}{|c|}{$\begin{array}{l}\mathrm{McN}=2.778 \\
\text { pValue }=0.18\end{array}$} & \multicolumn{4}{|c|}{$\begin{array}{l}\mathrm{McN}=5.444 \\
\mathrm{pValue}=0.039\end{array}$} \\
\hline & \multicolumn{2}{|c|}{ Sum } & \multicolumn{4}{|c|}{ eHospital } & \multicolumn{4}{|c|}{ Konkang In } & \multicolumn{4}{|c|}{ Konkang Sam } & \multicolumn{4}{|c|}{ Doctor } \\
\hline & & & \multicolumn{2}{|c|}{ Librarian } & Us & & Libra & arian & Us & er & Libra & arian & Us & er & Libra & arian & Us & er \\
\hline & Freq & $\%$ & Freq & $\%$ & Freq & $\%$ & Freq & $\%$ & Freq & $\%$ & Freq & $\%$ & Freq & $\%$ & Freq & $\%$ & Freq & $\%$ \\
\hline Pre-education & 42 & 100 & 0 & 0 & 1 & 2.4 & 0 & 0 & 4 & 9.5 & 0 & 0 & 5 & 11.9 & 0 & 0 & 4 & 9.5 \\
\hline Post-education & 42 & 100 & 0 & 0 & 0 & 0 & 3 & 25 & 6 & 14.3 & 2 & 16.7 & 9 & 21.4 & 0 & 0 & 6 & 14.3 \\
\hline & & & $\begin{array}{l}\text { McN } \\
\text { pValu }\end{array}$ & $\begin{array}{l}=0.5 \\
e=0\end{array}$ & & & $\begin{array}{l}\text { McN } \\
\text { pValu }\end{array}$ & $\begin{aligned}= & 2.66 \\
u e & =0\end{aligned}$ & & & $\begin{array}{l}\mathrm{McN}= \\
\text { pValue }\end{array}$ & $\begin{array}{l}=1 \\
e=0\end{array}$ & 25 & & & & & \\
\hline & Su & & & Docto & corea & & & Docto & crezic & & & MKh & alth & & & Med & & \\
\hline & & & Libr & Irian & Us & & Libra & arian & Us & er & Libra & arian & Us & er & Libra & arian & Us & er \\
\hline & Freq & $\%$ & Freq & $\%$ & Freq & $\%$ & Freq & $\%$ & Freq & $\%$ & Freq & $\%$ & Freq & $\%$ & Freq & $\%$ & Freq & $\%$ \\
\hline Pre-education & 42 & 100 & 0 & 0 & 2 & 4.8 & 0 & 0 & 1 & 2.4 & 2 & 16.7 & 4 & 9.5 & 0 & 0 & 1 & 2.4 \\
\hline Post-education & 42 & 100 & 1 & 8.3 & 6 & 14.3 & 0 & 0 & 0 & 0 & 5 & 41.7 & 15 & 35.7 & 2 & 16.7 & 7 & 16.7 \\
\hline & & & $\begin{array}{l}\mathrm{McN} \\
\mathrm{pVall}\end{array}$ & $\begin{array}{l}=4 \\
e=0\end{array}$ & & & & & & & $\begin{array}{l}\mathrm{McN}= \\
\text { pValue }\end{array}$ & $\begin{array}{l}=9.30 \\
e=0 .\end{array}$ & $\begin{array}{l}08 \\
003\end{array}$ & & $\begin{array}{l}\mathrm{Mcl} \\
\mathrm{pVal}\end{array}$ & $\begin{array}{l}=4.5 \\
=0 .\end{array}$ & & \\
\hline & Su & & & Vitam & inMD & & & ins MS & hea & Ith & & Eomec & dy.com & & & Hic & doc & \\
\hline & & & Libr & Irian & Us & & Libr & arian & Us & ser & Libra & arian & Us & & Libra & arian & Us & er \\
\hline & Freq & $\%$ & Freq & $\%$ & Freq & $\%$ & Freq & $\%$ & Freq & $\%$ & Freq & $\%$ & Freq & $\%$ & Freq & $\%$ & Freq & $\%$ \\
\hline Pre-education & 42 & 100 & 1 & 8.3 & 6 & 14.3 & 2 & 16.7 & 2 & 4.8 & 0 & 0 & 2 & 4.8 & 0 & 0 & 1 & 2.4 \\
\hline Post-education & 42 & 100 & 3 & 25 & 16 & 38.1 & 5 & 41.7 & 5 & 11.9 & 1 & 8.3 & 15 & 35.7 & 1 & 8.3 & 7 & 16.7 \\
\hline & & & $\begin{array}{l}\text { McN } \\
\text { pValı }\end{array}$ & $\begin{array}{l}=7.14 \\
e=0 .\end{array}$ & & & $\begin{array}{l}\mathrm{McN} \\
\mathrm{pValu}\end{array}$ & $\begin{array}{l}=1.8 \\
\text { ue }=0\end{array}$ & & & $\begin{array}{l}\mathrm{McN}= \\
\text { pValue }\end{array}$ & $\begin{array}{l}=11.2 \\
e=0 .\end{array}$ & $\begin{array}{l}27 \\
001 \\
\end{array}$ & & $\begin{array}{l}\mathrm{Mc} \\
\mathrm{pVa}\end{array}$ & $\begin{array}{l}6 \\
=0 .\end{array}$ & 31 & \\
\hline & Su & & & Healt & h MBC & & & Health & hosu & & & Oth & ers & & & & & \\
\hline & & & Libr & Irian & Us & ser & Libr & arian & Us & er & Libra & arian & Us & & & & & \\
\hline & Freq & $\%$ & Freq & $\%$ & Freq & $\%$ & Freq & $\%$ & Freq & $\%$ & Freq & $\%$ & Freq & $\%$ & & & & \\
\hline Pre-education & 42 & 100 & 0 & 0 & 5 & 11.9 & 6 & 50 & 8 & 19 & 2 & 16.7 & 3 & 7.1 & & & & \\
\hline Post-education & 42 & 100 & $\begin{array}{c}0 \\
\mathrm{McN} \\
\mathrm{pVal}\end{array}$ & $\begin{array}{c}0 \\
=0.66 \\
e=0 .\end{array}$ & $\begin{array}{l}7 \\
38\end{array}$ & 16.7 & $\begin{array}{c}8 \\
\mathrm{McN} \\
\text { pValu }\end{array}$ & $\begin{array}{r}66.7 \\
=0.2 \\
\mathrm{u}=1\end{array}$ & 9 & 21.4 & $\begin{array}{c}1 \\
\mathrm{McN}= \\
\text { pValue }\end{array}$ & $\begin{aligned} & 8.3 \\
= & 2, \\
e= & 0 .\end{aligned}$ & 1 & 2.4 & & & & \\
\hline
\end{tabular}

grew even higher afterward. This increase indicates that users have a high interest in $\mathrm{CHI}$-related seminars provided by public libraries (see table 6).

\section{Librarian Group}

\section{Resources for CHI Service}

Table 7 shows that information sources utilized by librarians for $\mathrm{CHI}$ service became more diverse after the training. The proportion of librarians using medical databases, which had not been used before the education, especially increased to 8.3 percent, as well as the proportion for news and media to 33.3 percent. The proportion of librarian participants using medical reference information sources increased from 16.7 percent to 41.7 percent, and that of using websites also increased from 8.3 percent to 58.3 percent. The $\mathrm{p}$-value for the website option was 0.03125 , which is statistically significant under 0.05 significance level. 


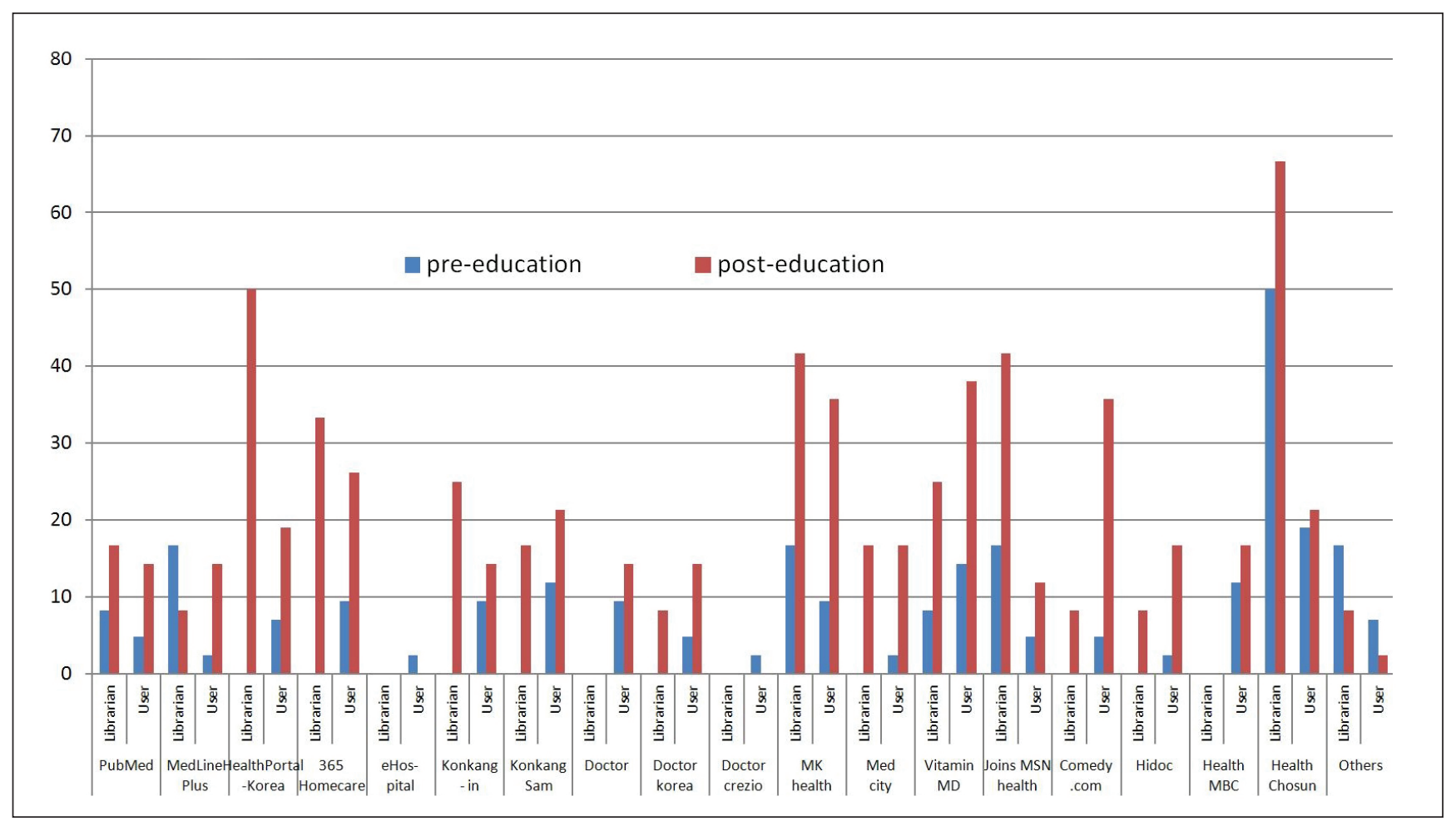

Figure 4. Experience using $\mathrm{CHI}$-related resources

\section{Time Needed for Answering CHI-Related Questions}

Taking into account the overall number of questions a public librarian receives from users in a day (100 percent), the study categorized the questions by those receiving an immediate response ( $0-3$ minutes to answer), those at a reference desk or on a phone call (takes 4 to 10 minutes), and those tasks requiring more than a day (requires consulting or additional research), and asked librarians what is the average proportion for each type of question from users. By comparing their averages, the researchers found that the response time required for answering users' questions increased after the program. The proportion of tasks requiring more than a day's work, especially, increased from 0 percent to 0.3 percent, indicating that librarian participants started to make requests, consult others, or conduct additional research before answering involved questions. This is likely related to an increase in interest and confidence about CHI-related questions (see table 8 and figure 5). The researchers could not find a significant difference in averages, but the increased standard deviation indicates that the librarians show very different behaviors after receiving the $\mathrm{CHI}$ education.

\section{Difficulties and Solutions in Answering Questions}

The study asked the librarians about difficulties in answering users' $\mathrm{CHI}$ questions and possible solutions for those difficulties. The questions fell into three categories:
1. Does answering $\mathrm{CHI}$ questions take librarians too much time? Using a five-point Likert scale, the results show that they feel that the time for answering $\mathrm{CHI}$ questions became shorter after receiving the education program. The mean decreased from 3.364 to 2.5 , but the p-value indicates that the difference is not statistically significant probably due to the small sample size.

2. Do librarians feel a lack of materials and information when answering CHI-related questions? The mean for this question decreased from 3.909 to 2.1 after the training, and the p-value (0.0078) indicates that the difference was statistically significant. Therefore, the education was effective in providing librarians with the ability to locate $\mathrm{CHI}$-related materials and information resources.

3. Do librarians tend to seek help from other libraries on CHI questions? Here, the mean increased after the training from 2.364 to 3.9. This indicates that the proportion of librarians who asked relevant institutes for help with answering CHI questions increased ( $p$ Value $=0.0273$ ). These results may also mean that librarians' attitudes changed from trying to solve questions within their libraries to actively requesting other institutes for reference information. In addition, this evidence suggests that the education enhanced their knowledge about relevant institutes and made them recognize that libraries are responsible for helping users answer $\mathrm{CHI}$ questions. 
Table 5. Useful CHI-related education contents

\begin{tabular}{|c|c|c|c|c|c|c|c|c|c|c|c|c|c|c|c|c|c|c|}
\hline \multirow[b]{4}{*}{ Pre-education } & \multirow{2}{*}{\multicolumn{2}{|c|}{ Sum }} & \multicolumn{4}{|c|}{$\begin{array}{l}\text { Information on } \\
\text { Specific Diseases or } \\
\text { Its Symptoms }\end{array}$} & \multicolumn{4}{|c|}{$\begin{array}{c}\text { Information about } \\
\text { Treatment of Certain } \\
\text { Diseases }\end{array}$} & \multicolumn{4}{|c|}{$\begin{array}{l}\text { Information about a } \\
\text { Particular Doctor }\end{array}$} & \multicolumn{4}{|c|}{$\begin{array}{l}\text { Information about } \\
\text { Health Insurance, } \\
\text { Health Benefits }\end{array}$} \\
\hline & & & \multicolumn{2}{|c|}{ Librarian } & \multicolumn{2}{|c|}{ User } & \multicolumn{2}{|c|}{ Librarian } & \multicolumn{2}{|c|}{ User } & \multicolumn{2}{|c|}{ Librarian } & \multicolumn{2}{|c|}{ User } & \multicolumn{2}{|c|}{ Librarian } & \multicolumn{2}{|c|}{ User } \\
\hline & Freq & $\%$ & Freq & $\%$ & Freq & $\%$ & Freq & $\%$ & Freq & $\%$ & Freq & $\%$ & Freq & $\%$ & Freq & & Freq & $\%$ \\
\hline & 12 & 100 & 4 & 33.3 & 20 & 47.6 & 3 & 25 & 13 & 31 & 1 & 8.3 & 2 & 4.8 & 3 & 25 & 12 & 28.6 \\
\hline \multirow[t]{4}{*}{ Post-education } & 12 & 100 & 7 & 58.3 & 14 & 33.3 & 3 & 25 & 9 & 21.4 & 1 & 8.3 & 4 & 9.5 & 4 & 33.3 & 12 & 28.6 \\
\hline & \multirow{2}{*}{\multicolumn{2}{|c|}{ Sum }} & \multicolumn{4}{|c|}{$\begin{array}{c}\text { Information about } \\
\text { Specific Hospitals and } \\
\text { Medical Centers }\end{array}$} & \multicolumn{4}{|c|}{$\begin{array}{l}\text { Information about } \\
\text { Alternative Medical } \\
\text { Treatment or } \\
\text { Medicine }\end{array}$} & \multicolumn{4}{|c|}{$\begin{array}{c}\text { Information on a } \\
\text { Specific Experimental } \\
\text { Drug or Treatment }\end{array}$} & \multicolumn{4}{|c|}{$\begin{array}{c}\text { Information on } \\
\text { Exercise and Fitness }\end{array}$} \\
\hline & & & \multicolumn{2}{|c|}{ Librarian } & \multicolumn{2}{|c|}{ User } & \multicolumn{2}{|c|}{ Librarian } & \multicolumn{2}{|c|}{ User } & \multicolumn{2}{|c|}{ Librarian } & \multicolumn{2}{|c|}{ User } & \multicolumn{2}{|c|}{ Librarian } & Us & er \\
\hline & Freq & $\%$ & Freq & $\%$ & Freq & $\%$ & Freq & $\%$ & Freq & $\%$ & Freq & $\%$ & Freq & $\%$ & Freq & $\%$ & Freq & $\%$ \\
\hline Pre-education & 12 & 100 & 4 & 33.3 & 6 & 14.3 & 4 & 33.3 & 7 & 16.7 & 2 & 16.7 & 6 & 14.3 & 8 & 66.7 & 19 & 45.2 \\
\hline Post-education & 12 & 100 & 6 & 50 & 9 & 21.4 & 1 & 8.3 & 8 & 19 & 2 & 16.7 & 5 & 11.9 & 7 & 58.3 & 16 & 38.1 \\
\hline & & & $\begin{array}{r}\text { In } \\
\text { Alcoh } \\
\text { a }\end{array}$ & $\begin{array}{l}\text { forma } \\
\text { nol Co } \\
\text { and Sc }\end{array}$ & $\begin{array}{l}\text { ation o } \\
\text { nsum } \\
\text { obriety }\end{array}$ & $\begin{array}{l}\text { on } \\
\text { ption } \\
y\end{array}$ & $\begin{array}{r}\text { Infor } \\
\text { a }\end{array}$ & $\begin{array}{l}\text { rmati } \\
\text { ind Nu }\end{array}$ & $\begin{array}{l}\text { on on [ } \\
\text { utrition }\end{array}$ & Diet & $\begin{array}{l}\text { Inf } \\
\text { Qui }\end{array}$ & itting & $\begin{array}{l}\text { ation o } \\
\text { Smok }\end{array}$ & & Inforn & matio & n on D & Drugs \\
\hline & & & Libra & arian & Us & ser & Libra & arian & Us & er & Libra & arian & Us & er & Libra & arian & Us & er \\
\hline & Freq & $\%$ & Freq & $\%$ & Freq & $\%$ & Freq & $\%$ & Freq & $\%$ & Freq & $\%$ & Freq & $\%$ & Freq & $\%$ & Freq & $\%$ \\
\hline Pre-education & 12 & 100 & 4 & 33.3 & 4 & 9.5 & 8 & 66.7 & 19 & 45.2 & 7 & 58.3 & 4 & 9.5 & 0 & 0 & 1 & 2.4 \\
\hline Post- & 12 & 100 & 2 & 16.7 & 3 & 7.1 & 6 & 50 & 10 & 23.8 & 4 & 33.3 & 1 & 2.4 & 0 & 0 & 0 & 0 \\
\hline & & & $\begin{array}{r}\text { Info } \\
\text { Se } \\
\text { sexu }\end{array}$ & $\begin{array}{l}\text { ormat } \\
\text { x (pre } \\
\text { Ially tr } \\
\text { dise }\end{array}$ & $\begin{array}{l}\text { ransmi } \\
\text { ases) }\end{array}$ & $\begin{array}{l}\text { out } \\
\text { cy, } \\
\text { itted }\end{array}$ & $\begin{array}{l}\text { Info } \\
\text { Dise }\end{array}$ & $\begin{array}{l}\text { ormati } \\
\text { ease P }\end{array}$ & $\begin{array}{l}\text { ion } a b c \\
\text { revent }\end{array}$ & $\begin{array}{l}\text { out } \\
\text { tion }\end{array}$ & $\begin{array}{l}\text { Info } \\
\text { Pres } \\
\text { an }\end{array}$ & $\begin{array}{l}\text { ormati } \\
\text { script } \\
\text { d Sid }\end{array}$ & $\begin{array}{l}\text { ion ab } \\
\text { ion Dr } \\
\text { e Effec }\end{array}$ & $\begin{array}{l}\text { out } \\
\text { ugs } \\
\text { ts }\end{array}$ & $\begin{array}{l}\text { Int } \\
\text { Dep } \\
\text { and }\end{array}$ & $\begin{array}{l}\text { forma } \\
\text { ressic } \\
\text { Men }\end{array}$ & $\begin{array}{l}\text { tion o } \\
\text { n, Stre } \\
\text { al IIIn }\end{array}$ & $\begin{array}{l}\text { on } \\
\text { ess, } \\
\text { less }\end{array}$ \\
\hline & & & Libra & arian & Us & ser & Libra & arian & Us & & Libra & arian & Us & & Libra & arian & Us & ser \\
\hline & Freq & $\%$ & Freq & $\%$ & Freq & $\%$ & Freq & $\%$ & Freq & $\%$ & Freq & $\%$ & Freq & $\%$ & Freq & $\%$ & Freq & $\%$ \\
\hline Pre-education & 12 & 100 & 6 & 50 & 2 & 4.8 & 6 & 50 & 19 & 45.2 & 1 & 8.3 & 8 & 19 & 6 & 50 & 15 & 35.7 \\
\hline Post-education & 12 & 100 & 1 & 8.3 & 0 & 0 & 6 & 50 & 16 & 38.1 & 3 & 25 & 9 & 21.4 & 6 & 50 & 9 & 21.4 \\
\hline & & & $\begin{array}{l}\text { Info } \\
\text { Rece }\end{array}$ & $\begin{array}{l}\text { ormat } \\
\text { ent Ou } \\
\text { Dis }\end{array}$ & $\begin{array}{l}\text { ion ab } \\
\text { tbreal } \\
\text { ease }\end{array}$ & $\begin{array}{l}\text { ks of } \\
\text { out }\end{array}$ & $\begin{array}{r}\text { Info } \\
\text { Healt }\end{array}$ & ormati & $\begin{array}{l}\text { ion } \mathrm{ab} \\
\text { ated Is }\end{array}$ & $\begin{array}{l}\text { out } \\
\text { ssues }\end{array}$ & $\begin{array}{l}\text { Info } \\
\text { Rece }\end{array}$ & $\begin{array}{l}\text { ormat } \\
\text { Dise }\end{array}$ & $\begin{array}{l}\text { on ab } \\
\text { tbreal } \\
\text { ase }\end{array}$ & $\begin{array}{l}\text { ut } \\
s \text { of }\end{array}$ & & Oth & & \\
\hline & & & Libra & arian & Us & ser & Libra & arian & Us & & Libra & arian & Us & er & Libra & arian & Us & er \\
\hline & Freq & $\%$ & Freq & $\%$ & Freq & $\%$ & Freq & $\%$ & Freq & $\%$ & Freq & $\%$ & Freq & $\%$ & Freq & $\%$ & Freq & $\%$ \\
\hline Pre-education & 12 & 100 & 6 & 50 & 11 & 26.2 & 10 & 83.3 & 6 & 14.3 & 8 & 66.7 & 7 & 16.7 & 0 & 0 & 0 & 0 \\
\hline Post-education & 12 & 100 & 6 & 50 & 10 & 23.8 & 8 & 66.7 & 9 & 21.4 & 6 & 50 & 13 & 31 & 0 & 0 & 1 & 2.4 \\
\hline
\end{tabular}

Librarian: stat $=-18$, pValue $=0.1548 /$ User: pValue of the information on diet and nutrition is 0.05 or less.

\section{User Group}

To measure the effect of the education program on users' ability to search for CHI on the Internet, and the study asked users to rate their degree of agreement on four questions.

First, how well they could search for health-related information on the Internet, rated on a five-point scale? The results show that users' searching ability improved dramatically after the program. While the proportion of users who chose "agree" and "strongly agree" increased from 50 percent to 61.9 percent, the proportion who selected "disagree" and "strongly disagree" decreased from 28.6 percent to 9.5 percent. The difference is statistically significant with p-value of 0.0039 .

Second, could users find exactly what they need on the Internet? It appears that the education program improved their abilities in this area as well. The proportion of users that selected "strongly agree" increased by 6 percent, and the proportion selecting "disagree" decreased from 26.2 percent to 9.5 percent, by as much as 16.7 percent. After the education program none of the users answered "strongly disagree" 
Table 6. Intention to participate in future health-related seminars/lectures/workshops

\begin{tabular}{|c|c|c|c|c|c|c|c|c|c|c|c|c|c|c|}
\hline \multirow[b]{2}{*}{ Librarian } & \multicolumn{2}{|c|}{ Sum } & \multicolumn{2}{|c|}{ Nonresponse } & \multicolumn{2}{|c|}{ Very High } & \multicolumn{2}{|c|}{ High } & \multicolumn{2}{|c|}{ Neutral } & \multicolumn{2}{|c|}{ Low } & \multirow[b]{2}{*}{ Mean } & \multirow[b]{2}{*}{ Std } \\
\hline & Freq & $\%$ & Freq & $\%$ & Freq & $\%$ & Freq & $\%$ & Freq & $\%$ & Freq & $\%$ & & \\
\hline Pre-education & 12 & 100 & & & 0 & 0 & 8 & 66.7 & 4 & 33.3 & & & 3.667 & 0.492 \\
\hline Post-education & 12 & 100 & & & 1 & 8.3 & 9 & 75 & 2 & 16.7 & & & 3.917 & 0.515 \\
\hline \multicolumn{15}{|l|}{ User } \\
\hline Pre-education & 42 & 100 & 2 & 4.8 & 3 & 7.1 & 19 & 45.2 & 15 & 35.7 & 3 & 7.1 & 3.55 & 0.749 \\
\hline Post-education & 42 & 100 & 0 & 0 & 8 & 19 & 25 & 59.5 & 7 & 16.7 & 2 & 4.8 & 3.929 & 0.745 \\
\hline
\end{tabular}

Librarian: stat $=6$; pValue $=0.4531 /$ User: stat $=40.5 ;$ pValue $=0.0024$

for this question. The p-value is 0.02 , which shows that the difference is significant under the 5 percent significance level.

Third, could users evaluate health-related information found on the Internet? The proportion who chose "agree" showed a dramatic increase from 16.7 percent to 54.7 percent. The proportion who selected disagree" deceased from 42.9 percent to 11.9 percent, a change of 31 percent. Five participants answered "strongly disagree" before the education program, but, afterward, no one chose this option. The p-value is 0.001 , which shows that the difference is very significant.

Fourth, are users familiar with reliable health information sources? Here, the proportion of positive answers increased from 9.5 percent to 54.7 percent, while the proportion of negative answers decreased from 42.8 percent to 4.8 percent. The $\mathrm{p}$-value is 0.0001 , which shows that the difference is very statistically significant. This indicates that the education program was very effective in terms of increasing users' knowledge about reliable information sources.

\section{Considerations to Improve Education Quality}

$\mathrm{CHI}$ education provided for public librarians and users is not a common occurrence in Korea, and CHI services and education provided by public libraries are largely unknown to the general public. The education provided by this research was a basic introductory level course, and the lectures and instructors were not highly qualified. Therefore, identifying ways to improve $\mathrm{CHI}$ education quality will be a cornerstone for future $\mathrm{CHI}$ education development.

After the education programs, the researchers measured the following aspects of efficiency: appropriateness of program level, interest of educational contents, usefulness of the information provided in the sessions, and necessity of including $\mathrm{CHI}$ education in the regular curriculum for public librarians and users:

- 75 percent of the librarians and 69 percent of the users answered that the level the programs were taught at was proper.

- 91 percent of the librarians and 76.2 percent of the users answered that the contents were interesting.

- 76.2 percent of the librarians and 91.7 percent of the users answered that the contents were useful. One of those users even answered that the contents were very useful.

- 50 percent of the librarians and 59.5 percent of the users indicated that it would be useful to include a $\mathrm{CHI}$ education program in the regular curriculum for public librarians and users

\section{DISCUSSION \& FUTURE RESEARCH}

Distribution of $\mathrm{CHI}$ is one of the librarian's recognizable roles, and health information literacy has become an important issue in many countries including the United States. ${ }^{32}$ This is because the users believe that various types of libraries, including public libraries, guarantee the authority for information access, and libraries are recognized as neutral, welcoming places in the community. ${ }^{33}$ Moreover, public libraries can play an important role in basic literacy training and providing $\mathrm{CHI}$ literacy programs. This study provided public librarians and users with $\mathrm{CHI}$ education experiences and measured the effect. Five research questions were posed at the start of the study, and answered by the results thus:

First, the researchers studied librarian and user familiarity with $\mathrm{CHI}$ terminologies, and 75 percent of librarians answered that they were unfamiliar or very unfamiliar. After the seminar, only 33 percent of them answered that they were not familiar. They were confident with providing reference services, but needed to understand basic terminologies to be confident with the CHI subject itself. Therefore education on terminologies needs to be included in librarian education and library schools should consider providing terminology lectures by experts in the relevant fields. In addition, 50 percent of the users answered that they were not familiar with terminologies before the education program, but only 9.6 percent of them answered so afterward. On the other hand, the responses that indicate that they are familiar increased from 4.8 percent to 21.4 percent. This indicates that the education for public library users significantly improved the users' familiarity with CHI education. Knowledge about CHI terminology is the most basic aspect of searching for health information, and therefore it is recommended to include this subject in health-related education.

Second, the researchers tried to establish what should be 
Table 7. Information sources utilized by librarians for $\mathrm{CHI}$ service

\begin{tabular}{|c|c|c|c|c|c|c|c|c|c|c|c|c|c|c|}
\hline & \multirow{2}{*}{\multicolumn{2}{|c|}{ Sum }} & \multicolumn{4}{|c|}{ News and Media } & \multicolumn{4}{|c|}{$\begin{array}{c}\text { Medical Journals, } \\
\text { Magazines (print material) }\end{array}$} & \multicolumn{4}{|c|}{ Medicine-Related Database } \\
\hline & & & \multicolumn{2}{|c|}{ Yes } & \multicolumn{2}{|c|}{ No } & \multicolumn{2}{|c|}{ Yes } & \multicolumn{2}{|c|}{ No } & \multicolumn{2}{|c|}{ Yes } & \multicolumn{2}{|c|}{ No } \\
\hline & Freq & $\%$ & freq & $\%$ & Freq & $\%$ & Freq & $\%$ & Freq & $\%$ & Freq & $\%$ & Freq & $\%$ \\
\hline Pre-education & 12 & 100 & 0 & 0 & 12 & 100 & 3 & 25 & 9 & 75 & 0 & 0 & 12 & 100 \\
\hline \multirow[t]{4}{*}{ Post-education } & 12 & 100 & 4 & 33.3 & 8 & 66.7 & 5 & 41.7 & 7 & 58.3 & 1 & 8.3 & 11 & 91.7 \\
\hline & \multirow{2}{*}{\multicolumn{2}{|c|}{ Sum }} & \multicolumn{4}{|c|}{ Medical Reference Resources } & \multicolumn{4}{|c|}{ Borrowed Books } & \multicolumn{4}{|c|}{ Website information } \\
\hline & & & \multicolumn{2}{|c|}{ Yes } & \multicolumn{2}{|c|}{ No } & \multicolumn{2}{|c|}{ Yes } & \multicolumn{2}{|c|}{ No } & \multicolumn{2}{|c|}{ Yes } & \multicolumn{2}{|c|}{ No } \\
\hline & Freq & $\%$ & freq & $\%$ & Freq & $\%$ & Freq & $\%$ & Freq & $\%$ & Freq & $\%$ & Freq & $\%$ \\
\hline Pre-education & 12 & 100 & 2 & 16.7 & 10 & 83.3 & 8 & 66.7 & 4 & 33.3 & 1 & 8.3 & 11 & 91.7 \\
\hline \multirow[t]{4}{*}{ Post-education } & 12 & 100 & 5 & 41.7 & 7 & 58.3 & 10 & 83.3 & 2 & 16.7 & 7 & 58.3 & 5 & 41.7 \\
\hline & \multirow{2}{*}{\multicolumn{2}{|c|}{ Sum }} & \multicolumn{4}{|c|}{$\begin{array}{l}\text { Aid from Another Librarian } \\
\text { (internal) }\end{array}$} & \multicolumn{4}{|c|}{$\begin{array}{l}\text { Aid from Another Librarian } \\
\text { (external) }\end{array}$} & & & & \\
\hline & & & \multicolumn{2}{|c|}{ Yes } & \multicolumn{2}{|c|}{ No } & \multicolumn{2}{|c|}{ Yes } & \multicolumn{2}{|c|}{ No } & & & & \\
\hline & Freq & $\%$ & freq & $\%$ & Freq & $\%$ & Freq & $\%$ & Freq & $\%$ & & & & \\
\hline Pre-education & 12 & 100 & 0 & 0 & 12 & 100 & 0 & 0 & 12 & 100 & & & & \\
\hline Post-education & 12 & 100 & 0 & 0 & 12 & 100 & 0 & 0 & 12 & 100 & & & & \\
\hline
\end{tabular}

the focus of future education by identifying the difficulties that librarians are experiencing when they are providing $\mathrm{CHI}$ reference services. The survey shows that public librarians experience many difficulties related to finding information sources, institutions, or experts. It seems that this increases both the time for processing one service request and the librarians' feelings of pressure from such service. After the education program, due to the increased knowledge on information sources and external support resources, the frequency of requesting aid from external institutions increased and the time for processing CHI-related reference service decreased.

Third, the researchers analyzed if CHI education improved the users' ability to find health-related information on the Internet. The results show that the program significantly improved users' ability to search for health-related information, find the exact information necessary, evaluate the accuracy of information found on the Internet, and find reliable health information sources. This suggests that education programs in public libraries can improve users' ability to utilize health information, and therefore public libraries should provide CHI-related education programs and contribute to overall health.

Fourth, the researchers sought to identify whether public librarians and users want CHI-related education and what $\mathrm{CHI}$ program contents fit their needs. In both pre- and postsurveys, none of the participants answered that they did not have any intention of participating in CHI-related education programs if they were provided. The proportion of librarians who answered that they intended to participate in health information seminars/lectures/workshops appeared to be very high. Moreover, after the training, the proportion of librarians who answered that they want to participate in CHI-related education increased from 66.7 percent to 83.3 percent, and this indicates that the program has affected their interest in and desire for $\mathrm{CHI}$ education. The contents they want to be provided during these subsequent education seminars are, in order: health-related information sources, information about particular diseases or symptoms, information about health insurance and medical benefits, information about particular hospitals or medical institutions, and information about prescription medications and their side effects. These results suggest that public librarians should have more opportunities for CHI-related education, and this education needs to include not only topics related to $\mathrm{CHI}$ sources and health information, but also topics about particular hospitals and medical institutions. The study also analyzed whether users want to be provided with CHI education from public libraries, and the results show that the education program had no effect on the public library users' ideas about the usefulness of education programs for maintaining their healthy lifestyle. This result is most likely because the education program was not developed based on the users' demands, and there has been no benchmarking. Therefore, comprehensive analysis on cases in other countries, developing education programs based on user demand, and development of health-related education programs through trial-and-error should be conducted. Since the development of education in this area is still in a very preliminary stage, continuing research on this is required.

Fifth, discussion on whether or not the education program offered significantly affected librarians' perceptions has important implications for institutions providing similar education programs in the future. As explained in the previous section, this study shows that $\mathrm{CHI}$ education is highly effective. One public librarian stated that " $\mathrm{CHI}$ service in public libraries will bring a revival to reference service," and another 
Table 8. Type of CHI-related questions

\begin{tabular}{|c|c|c|c|c|c|c|c|c|c|c|c|c|c|c|}
\hline & \multicolumn{2}{|c|}{ Sum } & \multicolumn{4}{|c|}{$\begin{array}{c}\text { Immediate Response } \\
\text { Questions }\end{array}$} & \multicolumn{4}{|c|}{$\begin{array}{c}\text { Reference Desk or Phone Call } \\
\text { Questions }\end{array}$} & \multicolumn{4}{|c|}{$\begin{array}{l}\text { Questions Requiring more } \\
\text { than One Day }\end{array}$} \\
\hline & Freq & $\%$ & Resp & Mean & Std & pValue & Resp & Mean & Std & pValue & Resp & Mean & Std & pValue \\
\hline Pre-education & 12 & 100 & 8 & 82.50 & 5.345 & 0.625 & 8 & 17.5 & 5.345 & 0.625 & 8 & 0.000 & 0.000 & 0.5 \\
\hline Post-education & 12 & 100 & 7 & 70.75 & 35.050 & & 7 & 29.0 & 35.070 & & 7 & 0.286 & 0.488 & \\
\hline
\end{tabular}

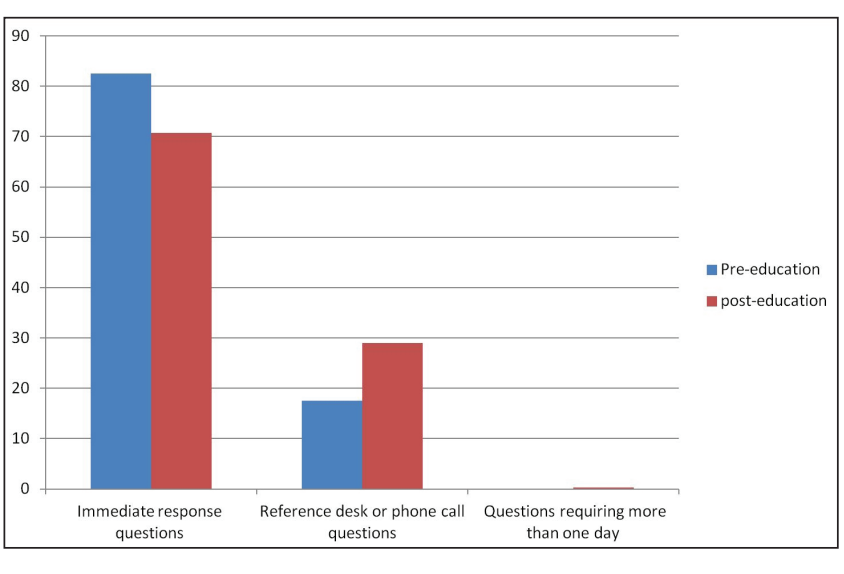

Figure 5. Type of CHI-related questions

librarian said that "demand for health information in the public library is increasing, and this seems to be related to an increase of senior users and interest in health." More detailed education program effects include: an increase in familiarity with CHI-related terminology, increase in amount and variety of $\mathrm{CHI}$ education for users, diversification of information sources used to provide $\mathrm{CHI}$-related service, decrease in time to provide reference service, and an ease of pressure caused by this lack of expert knowledge. The study also analyzed users' demand for CHI educational programs and the educational content of those programs, and the users' changing perceptions before and after the program. First, users demand education programs led by an expert, and educational contents about how to search for recent research information about diseases and disabilities, how to search and utilize health information databases, and how to identify reliable health information sources. Second, users showed significant improvement in knowledge on CHI-related sites and information sources through the program, and their frequency of information source usage increased. Third, their intention to participate again in health-related seminars provided by public libraries also improved. Moreover, the response that a $\mathrm{CHI}$-related education program needs to be included in the regular education curriculum has increased from 7.1 percent before the program to 59.5 percent after the program.

This study is the first attempt to provide a CHI education program to public library users in Korea, and the educational contents have some limitations and did not reflect users' demand. However, a more advanced CHI-related education program needs be developed based on users' needs identified by this research. The public library users' needs for $\mathrm{CHI}$ education identified by this research should be satisfied.

Though this study attempted to identify and address user demand, it is the first of its kind, especially compared to scholarship in other countries. Therefore, following future research is suggested:

- First, develop and apply various CHI-related education programs based on the public librarians' and users' demands, and continue improving upon their quality. Many such studies have already been conducted in other countries.

- Second, research on education programs for various types of libraries other than public libraries also needs to be conducted, because not only local residents require $\mathrm{CHI}$ services.

- Third, research on education for more varied types of users and utilizing more varied education method needs to be conducted. The research on $\mathrm{CHI}$ service is in a very preliminary stage and this education program was the first attempt in this area. Therefore, the contents need to be improved and intensified, and cooperation programs with local health institutes to invite the aid of health care experts are necessary.

\section{CONCLUSION}

The proportion of users searching for health information on the Internet is very high, but the proportion of users who can actually evaluate the accuracy and reliability of the acquired information is very low. ${ }^{34}$ This lack represents a potential threat to general health. Users actually require $\mathrm{CHI}$ service from public libraries and consider public libraries to be a very reliable information source..$^{35}$

The researchers recognized these problems, and tried to contribute to general health and expand the role of public libraries by providing health-related user education in a public library, which is the setting most closely related to local communities.

To this end, the researchers designed and developed an education program for both public librarians and users, analyzed its effects, and identified the ways to improve it. The study revealed the education program to be highly effective, especially in improving participants' knowledge of health information and health information sources, and in the identification of their needs. This study was the first attempt 


\section{FEATURE}

to analyze the effect of $\mathrm{CHI}$ education provided by a public library in Korea, and more design and the development of improved education programs are required. Moreover, national-level cooperation for CHI-related education program development and system establishment is necessary.

Foreign cases and previous research have already proven that public librarians contribute to users' ability to utilize $\mathrm{CHI}$, and therefore public librarians should play a key role in improving users' ability to utilize $\mathrm{CHI} .{ }^{36}$

\section{References}

1. Susan LaValley, "Delaware Health Source: Consumer Health Libraries and Health Literacy Outreach," Journal of Consumer Health on the Internet 13, no. 2 (2009): 180-86; Younghee Noh, "An Analysing of the Current CHI Services in Korean Public Libraries," Journal of the Korean Society for Library and Information Science 45, no. 2 (2011): 415-37; D. Eakin, S. J. Jackson, and G. G. Hannigan, "Consumer Health Information: Libraries as Partners," Bulletin of the Medical Library Association 68, no. 2 (1980): 220-29.

2. US Department of Health and Human Services, Healthy People 2010: Understanding and Improving Health, 2nd ed. (Washington, DC: US Government Printing Office, 2000), accessed March 17, 2012, www.health.gov/healthypeople; MLA Net, Medical Library Association Task Force on Health Information, Health Information Literacy Definitions, 2003, accessed January 1, 2011, www.mlanet.org/resources/healthlit/define.html.

3. Diane G. Schwartz et al., "Seniors Connect: A Partnership for Training between Health Care and Public Libraries," Medical Reference Services Quarterly 21, no. 3 (2002): 1-19; C. Helfner, "Brigham and Women's Hospital's Consumer Health Database Searching Seminar Series: The First Year," Journal of Consumer Health on the Internet 10, no. 2 (2006): 25-35; A. Richetelle, "Healthy websites: teaching consumers to search for quality health information on the Internet," Journal of Consumer Health on the Internet 7, no. 2(2003): 35-52.

4. Noh, "An Analysing of the Current CHI Services in Korean Public Libraries."

5. Jo-Ann M. Benedetti, "Strategies for Consumer Health Reference Training," Health Care on the Internet 6, (2002): 63-71.

6. Jessica L. Clark, "Consumer Health Staff Training in a Public Library Setting," Journal of Hospital Librarianship 3, no. 3 (2003): 53-62.

7. Siobhan Champ-Blackwell and Stephanie Weldon, "Free Online Consumer Health Classes," Journal of Consumer Health on the Internet 9, no. 3(2005): 37-42.

8. Mary Snyder, Jeffrey T. Huber, and Deborah Wegmann, "Education for Consumer Health: A Train the Trainer Collaboration," Health Care on the Internet 6, no. 4 (2002): 49-62.

9. C. Wessel, J. Wozar, and B. Epstein, "The Role of the Academic Medical Center Library in Training Public Librarians," Journal of the Medical Library Association 91, no. 3 (2003): 352-60.

10. N. Calabretta, S. Cavanaugh, and B. Swartz, "Growing a Web Page: The Evolution of a Consumer Health Resource," Journal of Consumer Health on the Internet 7, no. 3 (2003): 15-34.

11. Martha E. Stone, "Librarian-to-Librarian," Journal of Consumer Health on the Internet 8, no. 1 (2004): 1-11.

12. R. Parker and G. L. Kreps, "Library Outreach: Overcoming Health Literacy Challenges," Journal of the Medical Library Association 93, no. 4 (2005): S81-S85, accessed March 17, 2012, www.ncbi .nlm.nih.gov/pmc/articles/PMC1255757/pdf/i0025-7338-093 -04S-0081.pdf.

13. E. Burnham and EB. Peterson, "Health information literacy: a library case study," Library Trends 53, no. 3(2005): 422-33.

14. Lorie A. Kloda, "Health Information Literacy in Canadian Medi- cal Curricula: An Opportunity for Librarians?" Journal of Hospital Librarianship 8, no. 3 (2008): 314-22.

15. Ibid., 317

16. Schwartz et al., "Seniors Connect: A Partnership for Training between Health Care and Public Libraries," 1-19.

17. L. Wu et al., "Wiring Seniors to Quality Health Information," Journal of Consumer Health on the Internet 10, no. 2 (2006): 11-24.

18. Sabrian Kurtz-Rossi and Patricia Duguay, "Health Information Literacy Outreach: Improving Health Literacy and Access to Reliable Health Information in Rural Oxford County Maine," Journal of Consumer Health on the Internet 14, no. 4 (2010): 325-40.

19. Richetelle, "Healthy Websites."

20. Younghee Noh, Resources about Consumer Health Information Providers and Organizations in Korea (Resources Series for Consumer Health Information) (Paju, South Korea: JoenGeulteo, 2012); Younghee Noh, Resources about Consumer Health Information Websites in Korea (Resources Series for Consumer Health Information) (Paju, South Korea: JoenGeulteo, 2012); Younghee Noh, Resources about Consumer Health Information $D B$ and Website in Overseas (Resources Series for Consumer Health Information) (Paju, South Korea: JoenGeulteo, 2012); Younghee Noh, Resources about Consumer Health Information Providers and Organizations in Overseas (Resources Series for Consumer Health Information) (Paju, South Korea: JoenGeulteo, 2012); HealthPortalKorea, accessed March 17, 2012, www.healthportal-Korea.net.

21. Noh, "An Analysing of the Current CHI Services in Korean Public Libraries."

22. Younghee Noh, "A Study Comparing the Differing Perceptions of Public Librarians and Users in Assessing Consumer Health Information," Reference \& User Services Quarterly 52, no. 3 (2013): 231-42.

23. Wu et al., "Wiring Seniors to Quality Health Information."

24. Jeffrey and Wegmann, "Education for Consumer Health."

25. Wessel, Wozar, and Epstein, "The Role of the Academic Medical Center Library in Training Public Librarians."

26. Wu et al., "Wiring Seniors to Quality Health Information."

27. Kloda, "Health Information Literacy in Canadian Medical Curricula."

28. Richetelle, "Healthy Websites."

29. Noh, "A Study Comparing the Differing Perceptions of Public Librarians and Users in Assessing Consumer Health Information."

30. Sanghee Oh and Younghee Noh, "Online Health Information in South Korean Public Libraries: Developing Evaluation Criteria. Library \& Information Science Research 35, no. 1 (2013): 78-84; Champ-Blackwell and Weldon, "Free Online Consumer Health Classes."

31. Wessel, Wozar, and Epstein, "The Role of the Academic Medical Center Library in Training Public Librarians"; Champ-Blackwell and Weldon, "Free Online Consumer Health Classes."

32. Kloda, "Health Information Literacy in Canadian Medical Curricula?"

33. Burnham and Peterson, "Health Information Literacy."

34. G. Eysenbach and C. Köhler, "How Do Consumers Search for and Appraise Health Information on the World Wide web? Qualitative Study Using Focus Groups, Usability Tests, and In-Depth Interviews," BMJ 324, (March 9, 2002): 573-76; Pew Internet \& American Life Project, "Vital Decisions: How Internet Users Decide What Information to Trust When They or Their Loved Ones Are Sick," accessed May 6, 2012, www.pewInternet.org/ reports/toc. asp?Report $=59$.

35. Mary Jo Derring and John Harris, "Consumer Health Information Demand and Delivery: Implications for Libraries," Bulletin of the Medical Library Association 84, no. 2 (1996): 209-16; Noh, "An Analysing of the Current CHI Services in Korean Public Libraries"; Derring and Harris, "Consumer Health Information Demand and Delivery."

36. Kurtz-Rossi and Duguay, "Health Information Literacy Outreach." 